\title{
Feed of Siamese fighting fish, Betta splendens, (Regan, 1910) in open pond: live and formulated diets
}

\author{
L. H. Sipaúba-Tavares ${ }^{*}$, A. M. Appoloni ${ }^{a}$, J. B. K. Fernandes ${ }^{b}$ and R. N. Millan \\ aLaboratory of Limnology and Plankton Production, Aquaculture Center, Universidade Estadual Paulista - UNESP, \\ Via de Acesso Prof. Paulo Donato Castellani, s/n, Bairro Rural, CEP 14884-900, Jaboticabal, SP, Brazil \\ ${ }^{b}$ Ornamental Fish Laboratory, Aquaculture Center, Universidade Estadual Paulista - UNESP, Via de Acesso Prof. Paulo \\ Donato Castellani, s/n, Bairro Rural, CEP 14884-900, Jaboticabal, SP, Brazil \\ *e-mail: sipauba@caunesp.unesp.br
}

Received: June 30, 2014 - Accepted: March 23, 2015 - Distributed: May 31, 2016

(With 3 figures)

\begin{abstract}
The growth rate and percent survival of Betta splendens when submitted to formulated diet and live food treatments are evaluated. The three different diets were used and designated as: formulated diet (basal diet); live food diet (plankton) and mixed diet (formulated diet with plankton). The live food diet contained plankton belonging to an open pond. High mortality was reported with live food (plankton) treatment whereas higher percent survival occurred with formulated diet. Highest specific growth rate, weight gain and final weight were reported in the mixed diet treatment and were significantly different $(\mathrm{p}<0.01)$ from those in formulated diet and live food treatments. The gut contents of $B$. splendens in mixed diet and live food treatments comprised, Rotifera and Bacillariophyceae species in high percentages or rather, over $78 \%$ of total organisms. Lecane sp. was the most ingested zooplankton species by B. splendens in both treatments (mixed diet and live food), with the phytoplankton species Asterionella sp. and Melosira sp. respectively in mixed diet and in live food, respectively. Results indicated that the formulated diet influenced the water parameters dissolved oxygen, total suspended solids, total dissolved solids and $\mathrm{pH}$. The live food in the open pond was not enough to improve the growth rate and percent survival of $B$. splendens. The growth performance of $B$. splendens; had the best results with mixed diet which was capable of maintaining species's survival (82\%) and development in artificial conditions, benefiting the culture management of ornamental fish.
\end{abstract}

Keywords: ornamental fish, plankton, formulated diet, growth, aquaculture.

\section{Alimentação do peixe-de-briga, Betta splendens (Regan, 1910) em tanque externo de cultivo: dieta natural e formulada}

\begin{abstract}
Resumo
Foi avaliado o crescimento e sobrevivência de Betta splendens, quando submetidos à dieta formulada e alimento vivo. Foram utilizadas três dietas experimentais e designadas como: dieta formulada (ração); alimento vivo (plâncton) e dieta mista (ração com plâncton). O plâncton pertence ao tanque externo de cultivo. Alta mortalidade foi observada no tratamento com alimento vivo (plâncton) e a mais alta sobrevivência na dieta formulada. No tratamento com dieta mista foram observadas as maiores taxas de crescimento específico, ganho de peso e peso final, sendo significativamente diferentes $(\mathrm{p}<0,01)$ dos outros tratamentos. No conteúdo do trato digestório do $B$. splendens nos tratamentos dieta mista e alimento vivo, as espécies de Rotifera e Bacillariophyceae foram encontradas acima de $78 \%$ do total de organismos observados. Lecane sp. foi a espécie de zooplâncton mais ingerida por B. splendens em ambos os tratamentos (dieta mista e alimento vivo) e de fitoplâncton foi Asterionella sp. (dieta mista) e Melosira sp. (alimento vivo). Os resultados do presente estudo indicaram que a dieta formulada (ração) influenciou alguns parâmetros da água, como oxigênio dissolvido, sólidos totais solúveis, sólidos totais solúveis, sólidos totais suspensos e $\mathrm{pH}$, e o alimento vivo não foi suficiente para incrementar o crescimento e a sobrevivência de $B$. splendens. A dieta mista promoveu o maior crescimento do B. splendens possibilitando a sobrevivência de $82 \%$ e, o desenvolvimento desta espécie em condições artificiais, beneficiando o manejo do cultivo deste peixe ornamental.
\end{abstract}

Palavras-chave: peixes ornamentais, plâncton, dieta formulada, crescimento, aquicultura. 


\section{Introduction}

The species Betta splendens (Regan, 1910) is one of the best known and popular ornamental fish in the world. The species, native to the Mekong basin, Asia, belongs to the family Osphronemidae and it is one of the most important ornamental fish due to its body coloration, shape, economical and notable commercial value. Success in hatchery production of ornamental fish, regardless of age development for stocking in the grow-out production system is largely dependent on the availability of suitable live food and formulated diet for fingerlings and adults of B. splendens (Thongprajukaew et al., 2011).

Most ornamental fish culture still depends on the supply of live food and formulated diets, both of which crucial for lowering production costs and sustaining commercial activity. Although live food is believed to be the best protein source, but production is costly and sometimes unreliable. In addition it may provide suboptimum nutrition and cause high mortality (Puello-Cruz et al., 2010).

Consequently considerable efforts have been devoted to use a mixed diet in which, live food (plankton) and formulated diet are provided to evaluate the survival and growth performance of ornamental fish. Formulated diet coupled to live food has a comparable nutritional quality and maintain the percent survival and growth rate of ornamental fish at low costs on the global market (Lim et al., 2003).

Live food such as plankton preys has been widely used in fish aquaculture. The open pond has a great and diverse planktonic community that may provide live food to ornamental fish when appropriated methods are used. The planktonic community in the open pond may differ according to the environmental conditions and to its high variability depends on cultivation systems and nutrients input. Current assay used the plankton of the open pond to produce live food for $B$. splendens.

Many studies have focused on the fact that small live food such as planktonic Rotifera species are required for the development of fry production (Lim et al., 2003; Ogata and Kurokura, 2012). However, several studies reported that fish fed solely on formulated diets, have poor percent survival and low growth rate (Finn and Kapoor, 2008), whereas others researches insist that combination of live food and formulated diets in the early stage may provide higher growth rate and percent survival than live food (Rosenlund et al., 1997; Puello-Cruz et al., 2010).

Current study evaluated formulated diet and live food (plankton) to improve the growth rate and percent survival of 60-days-old B. splendens, during 49-days, with regard to three different diets (formulated diet, mixed diet and live food). It was hypothesized: 1)- the plankton biomass in the open pond was enough to improve growth development and survival of $B$. splendens; 2)- formulated diet, live food or mixed diet, are more efficient in supporting growth and survival of $B$. splendens; 3 )- the feed treatments influenced the water parameters.

\section{Material and Methods}

\subsection{Fish and rearing conditions}

The experimental work was performed with Betta splendens juveniles (60-days-old) in a pond at the Aquaculture Center $\left(22^{\circ} 5^{\prime} \mathrm{S}\right.$ and $\left.47^{\circ} 19^{\prime} \mathrm{W}\right)$. The fish were randomly divided in to five plastic boxes $(34 \times 54 \times 20 \mathrm{~cm})$, with 15 plastic bottles $(2 \mathrm{~L})$ in each box with one fish stocked in each bottle. The experiment was carried out during 49 days. Three different food treatments were provided in each plastic box (Figure 1). The five plastic

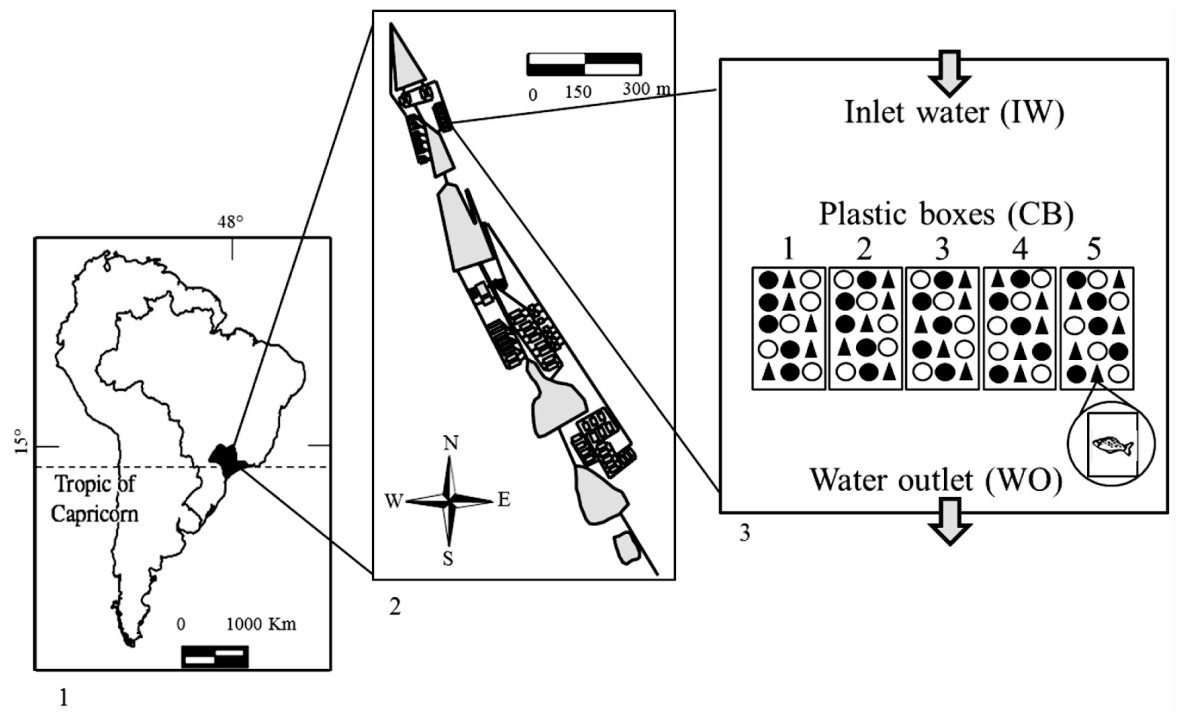

Figure 1. Geographic location (1), layout of Aquaculture Center (2) and outline of the flow-through open pond (3) used with the five plastic boxes and 15 plastic bottles $(2 \mathrm{~L})$ in each box, where: $\mathrm{o}=\mathrm{FD}+\mathrm{P}$ feed treatment (mixed diet); $\boldsymbol{\Delta}=\mathrm{FD}$ feed treatment (formulated diet $=$ basal diet $)$ and $\bullet=$ P feed treatment (live food $=$ plankton $)$. 
boxes were suspended $10-\mathrm{cm}$ over the surface, maintaining a $0.34 \mathrm{~m}$ water depth in the open pond. The open pond was rectangular in shape and 1.3 deep, with an aerial surface of $70 \mathrm{~m}^{2}$ in area and volume of $54.6 \mathrm{~m}^{3}$. The water supply was obtained from an upstream pond channeled to the open pond by an underground grid tubes. Water renovation (calculated from the discharged volume) was equivalent to $5 \%$ of the total pond volume per day. The B. splendens were fed on formulated diet ( $32 \%$ crude protein) at a rate of $3 \%$ weight.day ${ }^{-1}$ three times a day, except live food (plankton) treatment. The NPK (20-5-20) inorganic fertilizer was applied biweekly $\left(2.2 \mathrm{~g} . \mathrm{m}^{-2}\right)$ to open pond, while water levels in the open pond were maintained between 1.1 and $1.3 \mathrm{~m}$ throughout the period, compensating for seepage and evaporation losses. The initial weight and length of fish in the different treatments were $0.42 \pm 0.2 \mathrm{~g}$ and $2.64 \pm 0.06 \mathrm{~cm}$, respectively. Weight gain and total length of fish were measured individually. Growth performance parameters were as following formulate (Equation 1-4):

Condition factor $\left(\mathrm{g} \mathrm{cm}^{-3}\right)=100 \times\left(\mathrm{W} / \mathrm{L}^{3}\right)$

where: $\mathrm{W}=$ live body weight $(\mathrm{g})$ and $\mathrm{L}=$ total body length $(\mathrm{cm})$.

Specific growth rate (SGR) was calculated according to Kestemont and Stalmans (1992).

SGR $\left(\%\right.$ day $\left.^{-1}\right)=[\ln ($ Final weight $)-\ln$

(Initial weight)/number of days $] \times 100$

Percent survival $(\%)=[$ number of surviving

fish/total number of fish stocked] $\times 100$

Weight gain $(\mathrm{g})=$ final mean fish weight initial mean fish weight

\subsection{Feed treatments}

A basal diet was formulated to contain $32 \%$ crude protein and $16,891 \mathrm{~J} \mathrm{~g}^{-1}$, gross energy based on feed stuff values reported by Tamaru and Ako (1999). Three different diets were formulated designated as: $\mathrm{FD}=$ formulated diet, the water of the bottle from the water supply was not in contact with the water in the open pond; $\mathrm{FD}+\mathrm{P}=$ mixed diet, formulated diet with plankton from the open pond; $\mathrm{P}=$ live food, plankton from the open pond. The bottles with feed treatments FD+P and P had many holes for the circulation of water and plankton. Table 1 shows ingredients and formulation of feed treatments. The ingredients tested were ground in a hammer mill, mixed, moistened and pelleted in a meat grinder. The pellets were dried for 24 hours then fractionated and sieved to obtain a diameter of 0.71-1.00 mm.

\subsection{Environmental aspects}

Water and plankton parameters were estimated at 8:00 hours. Samples were collected from a depth of $10 \mathrm{~cm}$. Three samples sites were collected weekly during 49 days of experimental: IW= inlet water; $\mathrm{CB}=$ close to boxes and $\mathrm{WO}=$ water outlet (Figure 1). Temperature (Temp), $\mathrm{pH}$, conductivity (Cond) and dissolved oxygen (DO) were measured using multi-probe Horiba U-10, and water transparency (Transp) with a Secchi disk. Orthophosphate (OP), total phosphorus (TP), nitrite $\left(\mathrm{NO}_{2}\right)$ and nitrate $\left(\mathrm{NO}_{3}\right)$, were quantified with a spectrophotometer according to Golterman et al. (1978) and ammonia $\left(\mathrm{NH}_{4}\right)$ was quantified as describe by Koroleff (1976). Chlorophyll-a (Chl-a) concentration was determined by colorimetric analysis using a spectrophotometer after extraction with 90\% ethanol (Nusch, 1980). Total suspended solids (TSS) and total dissolved solids (TDS) were determined according to Boyd and Tucker (1992). Alkalinity (Alk) and inorganic carbons (free $\mathrm{CO}_{2}-\mathrm{FCO}_{2}$, Bicarbonate $-\mathrm{HCO}_{3}$ and total

Table 1. Formulation and proximate composition of the formulated diet (basal diet) for rearing Betta splendens juveniles in 49-days experiment.

\begin{tabular}{|c|c|}
\hline Ingredients $\left({\left.\mathrm{g} . \mathrm{kg}^{-1}\right)}^{-1}\right.$ & Basal diet \\
\hline Fish meal* & 150 \\
\hline Soybean meal* & 350 \\
\hline Wheat meal* & 290 \\
\hline Soybean Oil* & 160 \\
\hline Mineral-vitamin $\operatorname{mix} * *$ & 15 \\
\hline Vitamin C & 4.0 \\
\hline Dicalcium phosphate $^{1}$ & 27 \\
\hline Sugar cane bagasse ${ }^{2}$ & 4.0 \\
\hline \multicolumn{2}{|c|}{ Proximate composition (dry weight) } \\
\hline Dry matter $(\%)$ & 89.0 \\
\hline Crude protein $(\%)$ & 32.3 \\
\hline Digestible protein $(\%)$ & 28.2 \\
\hline Ether extract $(\%)$ & 5.0 \\
\hline $\operatorname{NFE}(\%)^{3}$ & 44.9 \\
\hline Crude fiber $(\%)$ & 3.7 \\
\hline Calcium $(\%)$ & 1.6 \\
\hline Phosphorus (\%) & 1.0 \\
\hline Gross energy $\left(\mathrm{J} . \mathrm{g}^{-1}\right)$ & 16,891 \\
\hline
\end{tabular}

*Fish meal, soybean meal, wheat meal and soybean oil obtained locally. The approximate composition of ingredients was Fish meal bagasse: $91.7 \%$ dry weight, $61.4 \%$ crude protein, $0.3 \%$ crude fiber, $20.5 \%$ ash, $17,552 \mathrm{~J}$ gross energy and $5.9 \%$ ether extract; soybean meal: $88.8 \%$ dry weight, $44.2 \%$ crude protein, $5.3 \%$ crude fiber, $6.0 \%$ ash, $17,096 \mathrm{~J}$ gross energy and $1.7 \%$ ether extract; wheat meal: $88.4 \%$ dry weight, $15.6 \%$ crude protein, $9.5 \%$ crude fiber, $16,360 \mathrm{~J}$ gross energy and $3.5 \%$ ether extract; soybean oil: $1.0 \%$ dry weight, $6.0 \%$ ash, $40,893 \mathrm{~J}$ gross energy and $99 \%$ ether extract. **Mineral-vitamin mix guaranteed levels per $\mathrm{Kg}$ of diet: vit $\mathrm{A}=500.000 \mathrm{IU}$; vit $\mathrm{D} 3=200.000$; vit $\mathrm{E}=5.000 \mathrm{IU} ; \mathrm{K} 3=1000 \mathrm{mg}$; vit. $\mathrm{B} 1=1500 \mathrm{mg}$; vit. $\mathrm{B} 12=1500 \mathrm{mg} ;$ Iron $=5000 \mathrm{mg} ;$ vit. $\mathrm{B} 12=4000 \mathrm{mg}$; folic acid $=500 \mathrm{mg}$; pantothenic acid $=4000 \mathrm{mg}$; biotin $=50 \mathrm{mg}$; choline $=40 \mathrm{~g} ; \mathrm{Co}=10 \mathrm{mg} ; \mathrm{Cu}=500 \mathrm{mg} ; \mathrm{Fe}=5000 \mathrm{mg} ; \mathrm{I}=50 \mathrm{mg}$; $\mathrm{Mn}=1500 \mathrm{mg} ; \mathrm{Se}=10 \mathrm{mg} ; \mathrm{Zn}=5000 \mathrm{mg} .{ }^{1} \mathrm{CaHPO}_{4} \cdot 2 \mathrm{H}_{2} \mathrm{O}$ : calcium supplement. ${ }^{2}$ Sugar cane bagasse obtained locally. The approximate composition of ingredients was sugar cane bagasse: $42.3 \%$ dry weight, $2.3 \%$ crude protein, $58.5 \%$ crude fiber, $2.5 \%$ ash, $16,870 \mathrm{~J}$ gross energy and $0.1 \%$ ether extract. ${ }^{3}$ Nitrogen free extract $=100-($ moisture content $+\%$ crude protein $+\%$ crude lipid $+\%$ crude ash $+\%$ crude fiber $)($ AOAC, 1990). 
$\mathrm{CO}_{2}-\mathrm{TCO}_{2}$ ) were determined according to Mackereth et al. (1978). Analyses were performed immediately after sampling or samples were duly stored under refrigeration.

For zooplankton, 10-L of water was filtered through $58 \mu \mathrm{m}$ pore net, concentrated to $50 \mathrm{~mL}$, and formalin was added to reach $4 \%$ final concentration. Cladocera and Copepoda species were identified in a reticulated acrylic chamber under stereomicroscope $(40 \times$ augmentation). Rotifera species were identified and counted in Sedgewick-Rafter chamber under a Leitz microscope $(100 \times$ augmentation $)$. For phytoplankton the quantification was estimated by counting the cells using Sedgewick-Rafter chamber during 30 minutes of sedimentation. The density of each species was calculated by counting all specimens totaling at least 100 individuals of the most frequent species or genus $(\mathrm{p}<0.05$; Lund et al., 1958). Plankton concentrations were expressed as number of individuals per $\mathrm{m}^{3}$ and percentage abundance. Plankton samples were only collected close to the plastic boxes $(\mathrm{CB})$.

\subsection{Gut contents analysis}

At the end of the experiment, ten fish were randomly selected from group that received live food plankton (P) and from the group that received formulated diet with plankton $(\mathrm{FD}+\mathrm{P})$, they were kept at low temperature $\left(-5^{\circ} \mathrm{C}\right)$ for 10 minutes (to avoid regurgitation) and subsequently fixed in $10 \%$ formalin. Food contents of the whole gut were analyzed quantitatively and qualitatively for their composition. Only food particles that were partially or not digested were analyzed.

\subsection{Statistical analysis}

Principal components analysis (PCA) was used to reduce the dimensionality of the environmental variables and to rank the variation of these variables between sites (Legendre and Legendre, 1998). These analyses were performed using the software Statistica 8.0 (STATSOFT INC., 2007). One-way ANOVA was used for growth performance to compare the effects of the experimental diets. Fisher's test was employed to test differences between average and were regarded significant when $p<0.05$. Spearman rank correlation (Rs) coefficient analysis was applied to compare to fish feeding (Siegel, 1975). This analysis was employed to study correlations between the available plankton in open pond and gut content of two feed treatments formulated diet with plankton $(\mathrm{FD}+\mathrm{P})$ and plankton $(\mathrm{P})$.

\section{Results}

Specific growth rate, weigh gain and final weight were higher $(\mathrm{p}<0.01)$ in FD+P treatment when compared with live food and formulated diet (Table 2). Fish showed lower specific growth rate, weigh gain and final weight in the live food $(\mathrm{P})$ treatment. No significant differences $(\mathrm{p}>0.05)$ for condition factor were reported between formulated diet, live food and mixed diet feed treatments. Fish showed higher total length with formulated diet (FD) and mixed diet $(\mathrm{FD}+\mathrm{P})$ feed treatments, which were significantly different with live food $(P)$ treatment $(p<0.01)$. Fish survival was lower in $\mathrm{P}$ feed treatment (44\%), whilst the highest percent survival (92\%) was recorded in FD feed treatment, which was different from percent survival $(80 \%)$ of FD+P feed treatment (Table 2).

Data obtained from water analysis were submitted to the principal component analysis (PCA) and results (open pond) are given in Figure 2. The first axis (PC1), accounting for $66 \%$ of the data variability is bipolar with three variables in its positive side (TDS, DO and $\mathrm{pH}$ ) and, more eutrophic was observed at the WO (water outlet) site associated with chlorophyll- $a$, alkalinity, temperature, conductivity, inorganic carbon, ammonia, nitrite, phosphorus, orthophosphate and transparency, with highest values. The second axis (PC2) accounting for a further $34 \%$ of the data variability, was associated only nitrate at a negative coefficient and related to IW site. Analyses of sites showed the formation of three different groups (Figure 2).

Since temperature was approximated $24^{\circ} \mathrm{C}$ during the experiment and $\mathrm{pH}$ was too high (>7.0), alkalinity (mean $49 \mathrm{mg} . \mathrm{L}^{-1}$ ) and bicarbonate (mean $60 \mathrm{mg} . \mathrm{L}^{-1}$ ) were high in the inlet water. Conductivity, chlorophyll- $a$, orthophosphate and total phosphorus had rather homogeneous values with peak in the second experimental week (7-days) after which they decreased until the end of the experiment. Dissolved oxygen (4.4-6.0 mg. $\mathrm{L}^{-1}$ ) was low in the 7-day experiment but latter increased until the end of the experiment (Figure 3).

The phytoplankton community in the open pond comprised of 19 taxa during the period under analysis. The group Chlorophyceae ( 7 species from 5 genera) was the most representative, followed by Bacillariophyceae (6 species), Zygnematophyceae (4 species from 2 genera), Euglenophyceae (1 species) and Cyanobacteria (1 species) (Table 3). Chlorella vulgaris, Chlorophyceae taxon, was the

Table 2. Biological indices obtained for Betta spleendens juveniles fed on formulated diet (basal diet - FD), live food (plankton - P) and mixed diet (formulate diet with plankton - FD + P) in 49-days experiment.

\begin{tabular}{lccc}
\hline \multicolumn{1}{c}{ Growth Performance } & \multicolumn{3}{c}{ Feed Treatments } \\
\hline \multicolumn{1}{c}{ Parameters } & FD & FD + P & P \\
\hline Final weight $(\mathrm{g})$ & $0.79 \pm 0.06^{\mathrm{b}}$ & $1.0 \pm 0.08^{\mathrm{a}}$ & $0.52 \pm 0.03^{\mathrm{c}}$ \\
Weight gain $(\mathrm{g})$ & $0.38 \pm 0.05^{\mathrm{b}}$ & $0.60 \pm 0.07^{\mathrm{a}}$ & $0.11 \pm 0.02^{\mathrm{c}}$ \\
Total length (cm) & $3.0 \pm 0.08^{\mathrm{a}}$ & $3.2 \pm 0.15^{\mathrm{a}}$ & $2.6 \pm 0.13^{\mathrm{b}}$ \\
Specific growth rate $\left(\%\right.$ day $\left.^{-1}\right)$ & $1.60 \pm 0.05^{\mathrm{b}}$ & $1.90 \pm 0.03^{\mathrm{a}}$ & $1.19 \pm 0.04^{\mathrm{c}}$ \\
Condition factor $\left(\mathrm{g} \cdot \mathrm{cm}^{-3}\right)$ & $0.03^{\mathrm{a}}$ & $0.03^{\mathrm{a}}$ & $0.03^{\mathrm{a}}$ \\
Survival $(\%)$ & $92^{\mathrm{a}}$ & $80^{\mathrm{b}}$ & $44^{\mathrm{c}}$ \\
\hline
\end{tabular}

Values in the same row with different superscripts are significantly different $(\mathrm{p}<0.05)$. 


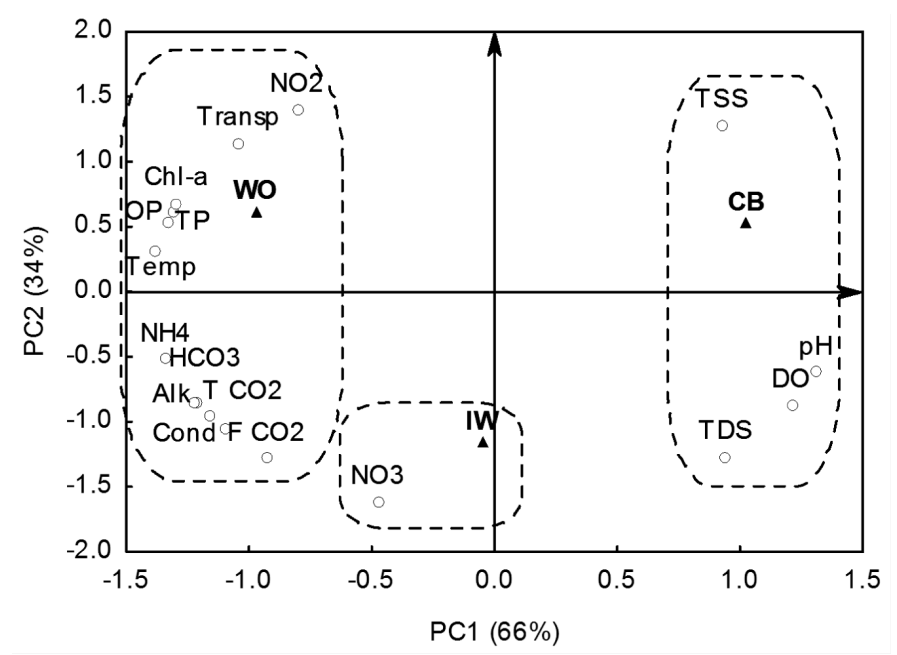

Figure 2. Interpolation of eigenvalues from the matrix of water variables from the open pond. The first two axes from the principal component analysis (PCA), where: $\mathrm{IW}=$ inlet water; $\mathrm{CB}=$ close boxes; $\mathrm{WO}=$ water outlet; open circle $=$ water variables; closed triangles $=$ sites.
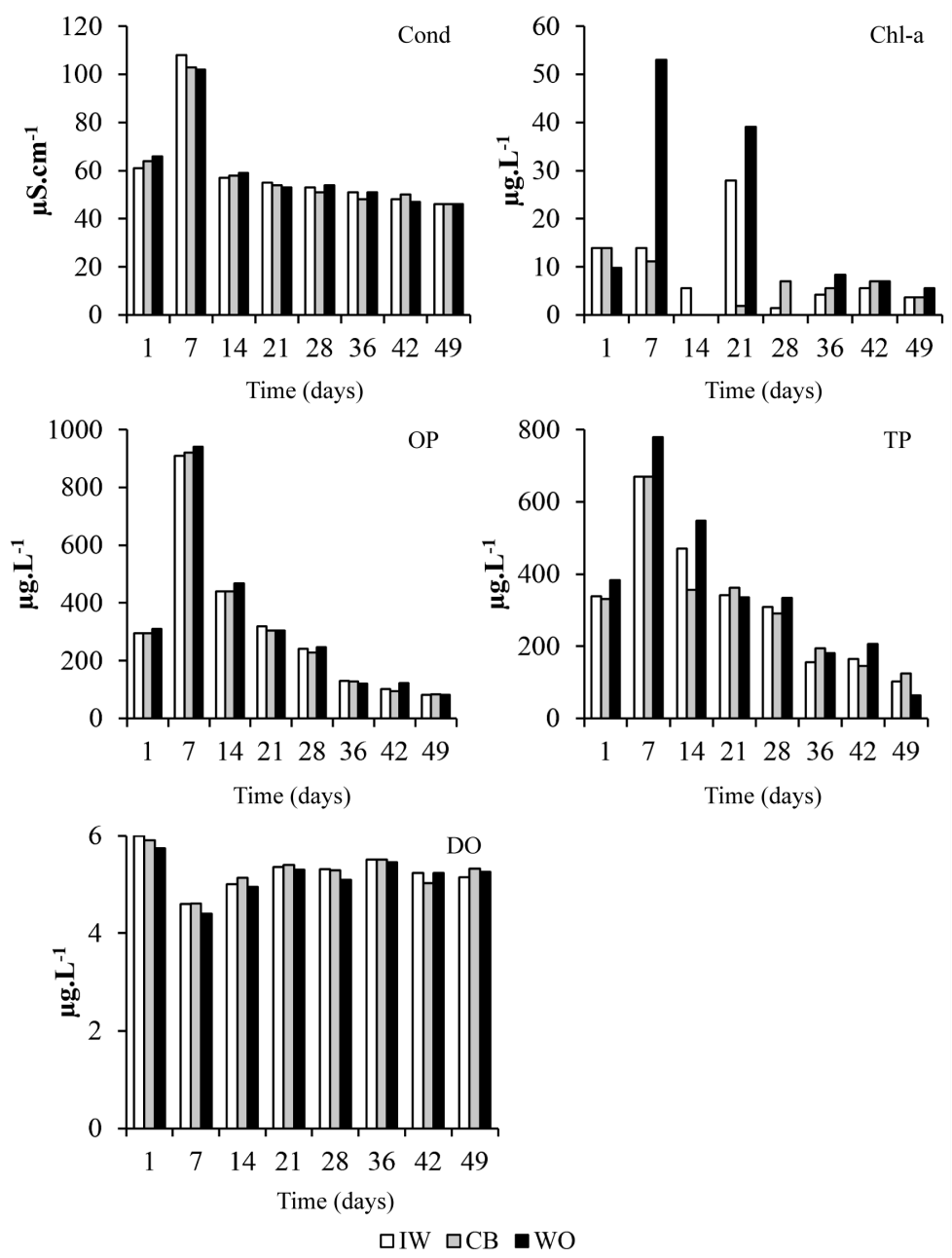

Figure 3. Weekly variation of conductivity (Cond); chlorophyll- $a$ (Chl-a), orthophosphate (OP), total phosphorus (TP) and dissolved oxygen (DO) at the sites IW (inlet water), CB (close boxes) and WO (water outlet), in a 49-day experiment. 
Table 3. Relative abundance (\%) and number of individuals. $\mathrm{m}^{3} \times 10^{4}$ (Ind.), grouped by taxa found in the gut contents of Betta splendens in feed treatments (FD+P and $\mathrm{P})$ and in the open pond.

\begin{tabular}{|c|c|c|c|c|c|c|}
\hline \multirow{3}{*}{ Taxon } & \multirow{2}{*}{\multicolumn{2}{|c|}{$\begin{array}{c}\text { Open } \\
\text { Pond } \\
\end{array}$}} & \multicolumn{4}{|c|}{ Feed Treatments } \\
\hline & & & \multicolumn{2}{|c|}{ FD+P } & \multicolumn{2}{|c|}{$\mathbf{P}$} \\
\hline & Ind. & $\%$ & Ind. & $\%$ & Ind. & $\%$ \\
\hline \multicolumn{7}{|l|}{ Zooplankton } \\
\hline \multicolumn{7}{|l|}{ Cladocera } \\
\hline Bosmina hagmani (Stingelin, 1904) & 18 & 2.0 & - & - & - & - \\
\hline Diaphanosoma birgei (Korinek, 1981) & 60 & 6.8 & 4 & 1.6 & 26 & 10.8 \\
\hline \multicolumn{7}{|l|}{ Copepoda } \\
\hline Argyrodiaptomus furcatus (Sars, 1901) & 204 & 23.2 & 0.5 & 0.2 & 2 & 0.8 \\
\hline nauplii & 408 & 46.4 & 8 & 3.2 & 10 & 4.1 \\
\hline Thermocyclops decipiens (Kiefer, 1929) & 1 & 0.1 & 2 & 0.7 & - & - \\
\hline nauplii & 23 & 2.6 & 4 & 1.6 & - & - \\
\hline \multicolumn{7}{|l|}{ Rotifera } \\
\hline Anuraeopsis sp. & 65 & 7.4 & 4 & 1.6 & - & - \\
\hline Asplanchna sp. & 3 & 0.3 & - & - & - & - \\
\hline Brachionus sp. & 8 & 0.9 & 22 & 8.9 & 38 & 15.7 \\
\hline Cephalodella sp. & 8 & 0.9 & 54 & 21.8 & 28 & 11.6 \\
\hline Colurella uncinata (Müller, 1773) & 3 & 0.3 & 44 & 17.7 & - & - \\
\hline Epiphanes brachionus (Ehrenberg, 1837) & 13 & 1.4 & & & & \\
\hline Lecane bulla (Gosse, 1851) & 20 & 2.3 & 28 & 11.3 & - & - \\
\hline Lecane quadridentata (Ehrenberg, 1832) & 3 & 0.3 & - & - & - & - \\
\hline Lecane sp. & 3 & 0.3 & 60 & 24.2 & 70 & 28.9 \\
\hline Polyarthra dolichoptera (Idelson, 1925) & 13 & 1.4 & & & & \\
\hline Proales sp. & 5 & 0.6 & 6 & 2.4 & 68 & 28.1 \\
\hline Proales doliaris (Rousselet, 1895) & 13 & 1.4 & - & - & - & - \\
\hline Trichocerca sp. & 13 & 1.4 & 12 & 4.8 & - & - \\
\hline \multicolumn{7}{|l|}{ Phytoplankton } \\
\hline \multicolumn{7}{|l|}{ Bacillariophyceae } \\
\hline Asterionella formosa (Hassal) & 212 & 5.1 & 738 & 11.5 & 616 & 16.7 \\
\hline Asterionella $\mathrm{sp}$ & 240 & 5.8 & 2380 & 37.1 & 990 & 26.9 \\
\hline Melosira $\mathrm{sp}$ & 704 & 17.0 & 1312 & 20.5 & 1296 & 35.2 \\
\hline Nitzschia amphibia (Grunow) & 59 & 1.4 & 26 & 0.4 & 22 & 0.6 \\
\hline Pinnularia sp. & 205 & 5.0 & 574 & 8.9 & 208 & 5.6 \\
\hline Surirella sp. & 20 & 0.5 & - & - & - & - \\
\hline \multicolumn{7}{|l|}{ Chlorophyceae } \\
\hline Chlorella vulgaris (Kessler \& Huss, 1992) & 2242 & 54.3 & 560 & 8.7 & 288 & 7.8 \\
\hline Coelastrum sp. & 45 & 1.1 & - & - & - & - \\
\hline Dictyosphaerium pulchellum (Wood) & 162 & 3.9 & 248 & 3.9 & 54 & 1.5 \\
\hline Pediastrum duplex (Meyen) & 33 & 0.8 & 24 & 0.4 & 16 & 0.4 \\
\hline Pediastrum tetras (Eherenberg) Ralfs & 4 & 0.1 & 2800 & 0.4 & 20 & 0.5 \\
\hline Scenedesmus bijugus (Meyen) & 40 & 1.0 & 4 & 0.1 & 4 & 0.1 \\
\hline Scenedesmus quadricauda (Turpin) Brébisson & 18 & 0.4 & 330 & 5.1 & 84 & 2.3 \\
\hline \multicolumn{7}{|l|}{ Cyanobacteria } \\
\hline Limnothrix sp. & 13 & 0.3 & - & - & - & - \\
\hline \multicolumn{7}{|l|}{ Euglenophyceae } \\
\hline Euglena sp. & 43 & 1.0 & 4 & 0.1 & 4 & 0.1 \\
\hline \multicolumn{7}{|l|}{ Zygnematophyceae } \\
\hline Micrasterias furcata (Ralf) & 15 & 0.4 & - & - & - & - \\
\hline Micrasterias sp. & 5 & 0.1 & - & - & - & - \\
\hline Microspora sp. & 71 & 1.7 & 178 & 2.8 & 84 & 2.3 \\
\hline Staurastrum sp. & 3 & 0.1 & 4 & 0.1 & - & - \\
\hline \multicolumn{7}{|l|}{ Others } \\
\hline Resting eggs & - & - & 170 & 100 & 226 & 100 \\
\hline
\end{tabular}

- not found. 
most abundant $(54.3 \%)$ of the phytoplankton community in the open pond. Melosira sp, Bacillariophyceae taxon, was the second most abundant (17\%) species in open pond, the abundance of the others species was below $6 \%$. The zooplankton community comprised Cladocera ( 2 species), Copepoda (2 species) and Rotifera (13 species from 10 genera). Copepoda were the most representative in the open pond due to Argyrodiaptomus furcatus adult and nauplii with a density of 204 ind. $\mathrm{m}^{-3} \times 10^{4}(23.2 \%)$ and 408 ind. $\mathrm{m}^{-3} \times 10^{4}(46.4 \%)$, respectively. Copepoda species represented $72.3 \%$ of the zooplankton community in the open pond (Table 3 ).

No significant difference $(\mathrm{p}>0.05)$ was registered between feed treatments FD+P $\left(\mathrm{R}_{\mathrm{s}}=0.42\right)$ and $\mathrm{P}\left(\mathrm{R}_{\mathrm{s}}=0.50\right)$ for gut contents of $B$. splendens (Table 3 ). The food organisms eaten by B. splendes were diverse and included phytoplankton. Both feed treatments were accepted by the ornamental fish. High ingestion of Melosira sp, Bacillariophyceae taxon, was probably due to its great abundance $(17 \%)$ in the open pond when, compared to that of others species, such as Asterionella sp and A. Formosa, Bacillariophyceae taxon, and Rotifera species such as Proales sp., Lecane sp., L. bulla, Colurella uncinata and Cephalodella sp (Table 3). Asterionella sp (FD+P) feed treatment and Melosira sp (P) feed treatment, represented more than $37 \%$ and $35 \%$ of phytoplankton ingested by ornamental fish, respectively. The Copepoda species had a higher abundance in the open pond but represented less than $16 \%$ in gut content, contrastingly to Proales sp and Lecane sp (Rotifera) which represented more than $28 \%$ of zooplankton ingested by $B$. splendens. A high amount of resting eggs in the gut content was observed. Cyanobacteria species were observed only in the water column in the open pond (Table 3 ).

\section{Discussion}

Betta splendens did not select $(\mathrm{p}>0.01)$ planktonic species in the treatments, and Bacillariophyceae and Rotifera were more representative in the gut contents. The same values of plankton was recorded in $B$. splendens fed on live food $(\mathrm{P})$ and mixed diet $(\mathrm{FD}+\mathrm{P})$ but the highest growth performance was recorded in mixed diet and indicated that the association of formulated diet and plankton was enough for fish metabolism which consequently resulted in a more suitable growth, than live food only or formulated diet only. The highest occurrence of algae and Rotifera in gut content revealed the planktivorous nature of feeding of $B$. splendens in the open pond.

Betta splendens fed on mixed diet (75\% formulated diet and $25 \%$ live food) registered the highest specific growth rate, weigh gain and condition factor. Mandal et al. (2010) observed that $25 \%$ replacement of live food with formulated diet was better for a higher growth rate of ornamental fish. These results agree with current study that the highest growth performance was obtained with FD+P feed treatment, but the highest percent survival occurred with FD feed treatment (90\%).
The low percent survival of $B$. splendens in $\mathrm{P}$ treatment is probably due to the high density of Copepoda (72.37\%), and the most these species have a rapid jumping movement, live preys may be less available to the fish for predation than Rotifera that represented $18.86 \%$ of the total zooplankton organisms in the open pond. Olivotto et al. (2010) demonstrated high growth rate and percent survival of Amphiprion clarkii, an ornamental fish, when a combined diet was used. Fish would spend less time and energy to ingest rapidly available artificial food, than to ingest the same volume of plankton by sucking water (Rahman et al., 2010). This argument explains the higher growth rate and percent survival of $B$. splendens in mixed diet $(\mathrm{FD}+\mathrm{P})$ and formulated diet (FD).

The feed treatments which influenced the abiotic properties of water and transparency were higher at WO site. Highest nitrogen compounds in the three sites were due to water supply. Highest amount of suspended materials (TSS and TDS) occurred close to the boxes and were caused by the decomposition of organic matter (feed waste). The constant water flow through the open pond carried the suspended material and moving feed waste to the WO site, causing increased of nutrients (TP, OP and $\mathrm{NH}_{4}$ ), phytoplankton biomass (Chl-a), carbon contents and water conductivity, which indicated an increase in eutrophication. No $\mathrm{pH}$ variation occurred in the open pond at different sites, possibly to photosynthesis. Results indicate that feeding not affect $\mathrm{pH}$ values. Similar observations were reported by Hassan (2011) on the common carp.

Results from the current study indicated that feed treatments influenced some water parameters such as TSS, TDS, DO and $\mathrm{pH}$, whereas live food $(\mathrm{P})$ in the open pond was not enough to improve the growth rate and percent survival of $B$. splendens. The growth and survival of $B$. splendens, registered their best results with mixed diet $(\mathrm{FD}+\mathrm{P})$, but the highest percent survival was obtained with formulated diet (FD). Hence, concluded mixed diet is a good tool for successfully in, maintaining the percent survival $(82 \%)$ and development of $B$. splendens in artificial conditions, for the benefit of the culture management of this ornamental fish.

\section{Acknowledgements}

The authors would like to thank the FAPESP for financial support (09/51946-6) and the scholarship to the second author (12/05527-4), and the colleagues of Limnology and Plankton Production Laboratory, and Ornamental Fish Laboratory for their instrumental assistance in field sampling and laboratory analysis.

\section{References}

ASSOCIATION OF OFFICIAL ANALYTICAL CHEMISTS AOAC. (1990). Official methods of analysis of the Association of Official Analytical Chemists. 15th ed. Washington, USA: AOAC.

BOYD, C.E. and TUCKER, C.S., 1992. Water quality and pond soil analyses for aquaculture. Auburn: Alabama Agricultural Experiment Station. 183 p. 
FINN, R.N. and KAPOOR, B.G., 2008. Fish larval physiology. Enfield: Science Publishers.

GOLTERMAN, H.L., CLYMO, R.S. and OHMSTAD, M.A.M., 1978. Methods for physical and chemical analysis of fresh water. 2nd ed. Oxford: Blackwell Scientific Publications. 213 p. IBP Handbook, no. 8.

HASSAN, A.A.E.R., 2011. Zooplankton as natural live food for three different fish species under concrete ponds with mono-and polyculture conditions. Egyptian Journal for Aquaculture, vol. 1 , no. 1 , pp. 27-40.

KESTEMONT, P. and STALMANS, J.M., 1992. Initial feeding of European minnow larvae Phoxinus phoxinus L. 1. Influence of diet and feeding level. Aquaculture (Amsterdam, Netherlands), vol. 104 , no. 3-4, pp. 327-340. http://dx.doi.org/10.1016/00448486(92)90214-6.

KOROLEFF, F., 1976. Determination of nutrients. In: E. GRASHOF and E. KREMLING, eds. Methods of seawater analysis. German: Verlag Chemie Wenhein. p 126-133.

LEGENDRE, P. and LEGENDRE, L., 1998. Numerical Ecology. Amsterdam: Elsevier Science B.V. 853 p.

LIM, L.C., DHERT, P. and SORGELOOS, P., 2003. Recent developement in the application of live feeds in the freshwater ornamental fish culture. Aquaculture (Amsterdam, Netherlands), vol. 227, no. 1-4, pp. 219-331. http://dx.doi.org/10.1016/S00448486(03)00512-X.

LUND, J.W.G., KIPLING, C. and LE CREN, E.D., 1958. The inverted microscopic method of estimating algal numbers and the statistical basis of estimations by counting. Hydrobiologia, vol. 12, no. 2, pp. 143-170. http://dx.doi.org/10.1007/BF00007865.

MACKERETH, F.J.H., HERON, J. and TALLING, F.J., 1978. Water analysis: some revised methods for limnologists. England: Titus Wilson and Son. 124 p.

MANDAL, S.C., SAHU, N.P., KOHLI, M.P.S., DAS, P., GUPTA, S.K. and MUNILKUMAR, S., 2010. Replacement of live feed by formulated feed: effect on the growth and spawning performance of Siamese fighting fish (Betta splendens, Regan, 1910). Aquaculture Research, vol. 41, no. 11, pp. 1707-1716. http://dx.doi.org/10.1111/j.1365-2109.2010.02564.x.

NUSCH, E.A., 1980. Comparison of different methods for chorophyll and phaeopigments determination. Archiv für Hydrobiologie, vol. 14 , pp. 4-36.
OGATA, Y. and KUROKURA, H., 2012. Use of the freshwater rotifer Brachionus angularis as the first food for larvae of the Siamese fighting fish Betta splendens. Fisheries Science, vol. 78, no. 6, pp. 109-112. http://dx.doi.org/10.1007/s12562-011-0420-1.

OLIVOTTO, I., TOKLE, N.E., NOZZI, V., COSSIGNANI, L. and CARNEVALI, O., 2010. Preserved copepods as a new technology for the marine ornamental fish aquaculture: A feeding study. Aquaculture (Amsterdam, Netherlands), vol. 308, no. 3-4, pp. 124-131. http://dx.doi.org/10.1016/j.aquaculture.2010.08.033.

PUELLO-CRUZ, A.C., VELASCO-BLANCO, G., MARTÍNEZRODRÍGUEZ, I.E., FELIX-RAMOS, E. and VOLTOLINA, D., 2010. Growth and survival of Siamese fighting, Betta splendens, larvae at low salinity and with different diets. Journal of the World Aquaculture Society, vol. 41, no. 5, pp. 823-828. http://dx.doi. org/10.1111/j.1749-7345.2010.00425.x.

RAHMAN, M.M., KODOWAKI, S., BALCOMBE, R. and WAHAB, M.A., 2010. Common carp (Cyprinus carpio L.) alters its feeding niche in response to changing food resources: direct observations in simulated ponds. Ecological Research, vol. 25, no. 2, pp. 303-309. http://dx.doi.org/10.1007/s11284-009-0657-7.

ROSENLUND, G., STOSS, J. and TALBOT, C., 1997. Cofeeding marine fish larvae with inert and live diets. Aquaculture (Amsterdam, Netherlands), vol. 155, no. 1-4, pp. 183-191. http:// dx.doi.org/10.1016/S0044-8486(97)00116-6.

SIEGEL, S., 1975 Non-parametric statistics for the behavioral sciences. São Paulo: McGraw-Hill. 350 p.

STATSOFT INC., 2007 [viewed 5 March 2014]. STATISTICA (Data Analysis Software System), version 8 [online]. Available from: www.Statsoft.com.

TAMARU, C.S. and AKO, H., 1999. Using commercial feeds for the culture of freshwater ornamental fishes in Hawaii. Technical Report, vol. 28, no. 1, pp. 109-119.

THONGPRAJUKAEW, K., KOVITVADHI, U., KOVITVADHI, S., SOMSUEB, P. and RUNGRUANGSAK-TORRISSEN, K., 2011. Effects of different modified diets on growth, digestive enzyme activities and muscle compositions in juvenile Siamese fighting fish (Betta splendens, Regan, 1910). Aquaculture (Amsterdam, Netherlands), vol. 322-323, no. 1-2, pp. 1-9. http:// dx.doi.org/10.1016/j.aquaculture.2011.10.006. 